\title{
潮間帯付着生物相による海域環境の定量評価指数の提案 一大阪湾湾奥をケーススタディとして一
}

\author{
吉村直孝 $^{1} \cdot$ 上月康則 ${ }^{2} \cdot$ 村上仁士 $^{3}$
}

\begin{abstract}
生物相による環境評価方法の一つに指標生物法がある。この方法は，環境を指標する種類の出現の有無によって簡単に環 境を評価できる利点があるが，指標生物の出現が無い場合は評価ができず，定量的な取り扱いが困難等の欠点が指摘されて いる. 本研究では, 容易に観察が可能な潮間帯の付着生物を対象に, 大阪湾湾奥 48 地点のコンクリート構造物で実施した フィールド調查の結果に基づき, 海域環境の新しい数值評価方法として，指標生物の特性を利用した生物相評価指数 (IF) を提案する.この指数による海域環境の定量評価は, その場の水質環境をよく反映し, 有用性が高いと考えられる.
\end{abstract}

\section{1. 緒言}

生物調査で得られたデータに基づく海域環境の評価は, 一般に出現種類数および現存量の多少によるものが多く, 生物相の情報を利用した評価は少ない。

生物相を利用した環境評価方法の一つに指標生物法が ある。この方法は，ある特定の環境条件に対応した分布 特性を有する生物の生理および生態を利用した方法であ り，環境を指標する種類の出現の有無によって簡単に環 境を評価できる利点があるが，指標生物の出現が無い場 合は評価ができず，定量的な取り扱いが困難であり，特 に海域では指標生物の選定が困難である等の欠点が指摘 されている（吉田，1983；伊藤，1998）.

本研究は, 容易に観察が可能な潮間帯の付着生物を対 象に，大阪湾湾奥で実施したフィールド調査の結果から， 新たに指標生物を選定し，指標生物の特性を利用した生 物相による海域環境の新しい数值評価方法を提案し，そ の有用性について検討を行った。

\section{2. フィールド調査}

\section{(1) 調 査 概 要}

フィールド調査の実施概要および調査地点の位置を 図-1に示した，調查時期は夏季（2004 年 9 月 11-12 日） および春季（2005 年 5 月 4-5 日）とし，毎回 2 日間の 調査を実施した。調査場所は, 調査 1 日目が堺市（堺泉 北港）から泉佐野市（りんくう公園前）までの 28 地点 (No.1-28), 調查 2 日目が大阪市（大阪港）から神戸市 (須磨港) までの 20 地点（No.31-50), 合計 48 地点とし た (春季の調査地点 No.22 は未調査).

調査地点はコンクリート製の直立ケーソン（スリット

\footnotetext{
1 学生会員 水産修 徳島大学大学院工学研究科

2 正 会 員 博(工) 德島大学大学院ソシオテクノサイエンス研究部助教 授

3 フェロー 工博 徳島大学大学院ソシオテクノサイエンス研究部教授
}

を含む）または消波ブロックとし，沖側が閉ざされてい ない沖向きの基盤面のある箇所とした.

調查内容は潮間帯の付着生物（付着植物および付着動 物）の出現種類の確認，記録とし，調查方法は船上から の目視観察とした，具体的には，作業船 1 隻を借り上げ, 調査地点まで海上を移動し，可能な限り基盤面に近寄り， 船上から肉眼または双眼鏡を使って，海面上および海面 下（概ね D.L.+1.5 m から $0.0 \mathrm{~m}$ までの範囲）に分布し ている生物の種類を確認，記録し，種類の判別が困難な 生物は所属の判別が可能な分類群を記録した。また，付 着植物では藍藻綱抢よび珪藻網等の微小藻類，付着動物 では潮上帯に生息する動物（タマキビおよびイワフジッ ボ等）および魚類は調查対象から除いた。

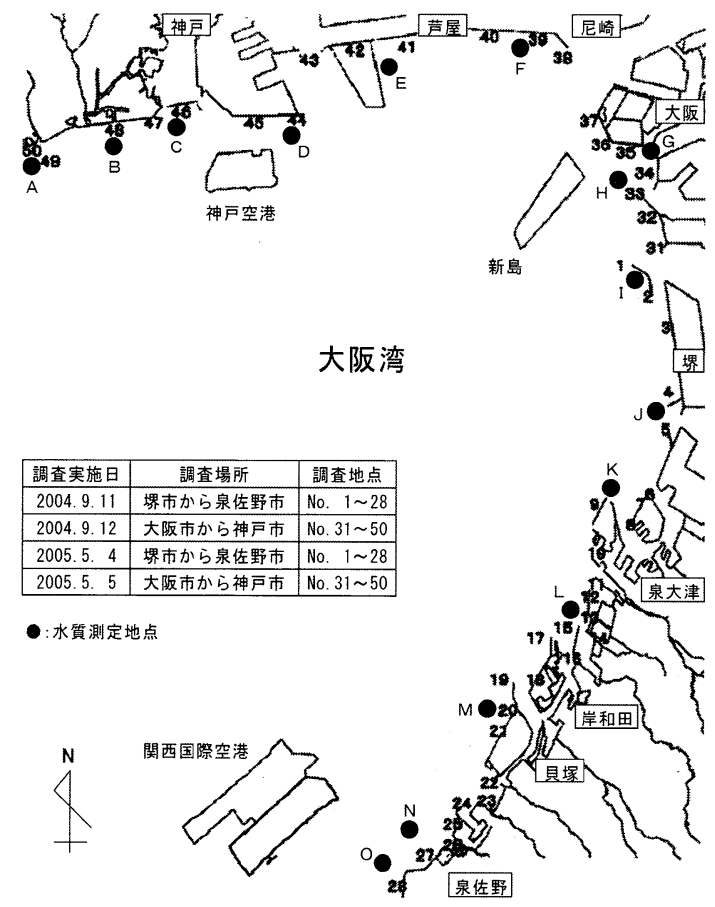

図-1 フィールド調査の実施概要と調査地点等の位置 
表-1 (a) 付着植物の出現種類リストと出現地点数

\begin{tabular}{|c|c|c|c|c|}
\hline 分 類 & \multicolumn{2}{|c|}{ 種類名（○は既知の指標生物を示す） } & 夏 & 春 \\
\hline \multirow{9}{*}{ 紅藻綱 } & ○アマノリ属 & Porphyra sp. & & 2 \\
\hline & ママクサ & Gelidium elegans & 1 & 3 \\
\hline & ○ツノマタ属 & Chondrus spp. & 12 & 8 \\
\hline & フダラク & Grateloupia lanceolata & 1 & 27 \\
\hline & ○ムカデノリ科 & Halymeniaceae & 1 & 10 \\
\hline & ○オキツノリ & Ahnfeltiopsis flabelliformis & & 2 \\
\hline & ○ベニスナゴ & Schizymenia dubyi & 2 & \\
\hline & ○カバノリ & Gracilaria textorii & & 2 \\
\hline & イギス目 & Ceramiales & 3 & 12 \\
\hline \multirow{4}{*}{ 褐藻綱 } & フクロノリ & Colpomenia sinuosa & & 2 \\
\hline & ワワカメ & Undaria pinnatifida & & 17 \\
\hline & ○カジメ属 & Ecklonia sp. & 1 & \\
\hline & タマハハキモク & Sargassum muticum & & 4 \\
\hline \multirow{5}{*}{ アオサ藻網 } & ○アオサ属 & Ulva sp. & 34 & 42 \\
\hline & ○アオノリ属 & Enteromorpha spp. & 38 & \\
\hline & ○シオグサ属 & Cladophora sp. & & 4 \\
\hline & ・ハネモ属 & Bryopsis sp. & & 3 \\
\hline & ミル & Codium fragile & 5 & 1 \\
\hline \multicolumn{3}{|c|}{ 全 48 地点におりりる出現種類数 } & 10 & 15 \\
\hline
\end{tabular}

なお，付着生物の表記については，目より上位の分類 単位に属する分類群の名称および配列は八杉ほか （1996）に従い，科より下位の分類単位に属する分類群 の名称は, 付着植物で田中・中村 (2004), 付着動物で は西村 $(1992 \cdot 1995)$, 特に軟体動物門に属する動物に ついては奥谷（2000）に従った.

\section{(2) 調 査結 果}

フィールド調查による潮間帯の付着植物の出現種類り ストおよび種類別出現地点数を表-1(a)に示した. 確認 された付着植物は，夏季が 10 種類であったのに対して， 春季は 15 種類とやや多く, 夏季に比べて春季の方が多 い傾向を示した. 全体では紅藻綱が 9 種類, 褐藻綱が 4 種類, アオサ藻綱が 5 種類, 合計 18 種類が確認された. 2 回のフィールド調査を通して最も多くの調査地点で確 認された種類はアオサ属であり, 次いでアオノリ属, フ ダラク, ツノマタ属の順に多かった。

また, フィールド調査による潮間帯の付着動物の出現 種類リストおよび種類別出現地点数を表-1(b)に示した. 確認された付着動物は, 夏季が 18 種類であったのに対 して, 春季は 27 種類とやや多く, 付着植物と同様の傾 向を示した. 全体では軟体動物門が 10 種類, 節足動物 門が 6 種類, 春索動物門が 4 種類, その他の動物門が 7 種類, 合計 27 種類が確認された. 2 回のフィールド調 査を通して最も多くの調査地点で確認された種類はイボ ニシおよびマガキであり, 次いでムラサキイガイ, タテ ジマイソギンチャク, ツタノハガイ亜目, カラマツガイ の順に多かった.
表-1 (b) 付着動物の出現種類リストと出現地点数

\begin{tabular}{|c|c|c|c|c|}
\hline 分 類 & \multicolumn{2}{|c|}{ 種類名（○は既知の指標生物を示す） } & 夏 & 春 \\
\hline \multirow{2}{*}{ 海綿動物門 } & ○ダイダイイソカイメン & Halichondria japonica & 9 & 2 \\
\hline & 普通海綿網 & Demospongiae & & 4 \\
\hline \multirow{2}{*}{ 刺胞動物門 } & タテジマイソギンチャク & Haliplanella lineata & 34 & 27 \\
\hline & イソギンチャク目 & Actiniaria & 1 & 3 \\
\hline \multirow{10}{*}{ 軟体動物門 } & ○ウスヒザラガイ亜目 & Ischnochitonina & 18 & 9 \\
\hline & ツタノハガイ亜目 & Patellina & 20 & 30 \\
\hline & イボニシ & Thais clavigera & 45 & 30 \\
\hline & レイシガイ & Thais bronni & & 2 \\
\hline & カラマツガイ & Siphonaria japonica & 4 & 45 \\
\hline & ○ムラサキイガイ & Mytilus galloprovincialis & 20 & 49 \\
\hline & ミドリイガイ & Perna viridis & & 1 \\
\hline & ○ナミマガシワ & Anomia chinensis & & 6 \\
\hline & ○ケガキ & Saccostrea kegaki & & 3 \\
\hline & ママガキ & Crassostrea gigas & 45 & 30 \\
\hline 環形動物門 & ○カンザシゴカイ科 & Serpulidae & 13 & 4 \\
\hline \multirow{6}{*}{ 節足動物門 } & のカメノテ & Capitulum mitella & 7 & 2 \\
\hline & ○クロフジッボ & Tetraclita japonica & 15 & 21 \\
\hline & のアカフジツボ & Megabalanus rosa & 1 & 2 \\
\hline & ○タテジマフジッボ & Balanus amphitrite & 2 & 1 \\
\hline & フナムシ & Ligia exotica & 14 & 3 \\
\hline & ○イソガニ & Hemigrapsus sanguineus & 13 & 4 \\
\hline 苔虫動物門 & ○フサコケムシ科 & Bugulidae & 7 & 2 \\
\hline 棘皮動物門 & イトマキヒトデ & Asterina pectinifera & 3 & \\
\hline \multirow{4}{*}{ 脊索動物門 } & エボヤ & Styela clava & & 3 \\
\hline & ○シロボヤ & Styela plicata & 3 & 4 \\
\hline & ○ユウレイボヤ属 & Ciona sp. & & 1 \\
\hline & ホヤ網（群体性） & Ascidiacea & & 4 \\
\hline \multicolumn{3}{|c|}{ 全 48 地点における出現種類数 } & 18 & 27 \\
\hline
\end{tabular}

\section{3. 検 討 結 果}

\section{（1）海域環境のランク分け}

吉田 (1983), 横浜市環境保全局（2002）を参考に, 海域環境の指標である 3 つの項目（富栄養度, 内湾性, 水の污れ）および項目間の関連性に着目し, 潮間帯の付 着生物相により評価する海域環境を I から V までの 5 段 階にランク分けした. その結果を表-2 に示した.

また, 各ランクが示す海域環境の目安として, 吉田 （1983）による夏季の水質（5 項目）を示すと, ランク I (過栄養) では透明度が $3 \mathrm{~m}$ 以下, COD が $3-10 \mathrm{O}_{2}$ ppm, DIN が 10-100 $\mu \mathrm{g}-\mathrm{at} . \mathrm{N} / \mathrm{L}$, DIP が 1-10 $\mu \mathrm{g}$-at. $\mathrm{P} / \mathrm{L}$, Chl.a が 10-200 mg/m³ , ランク III (富栄養) では 透明度が $3-10 \mathrm{~m}, \mathrm{COD}$ が 1-3 $\mathrm{O}_{2} \mathrm{ppm}, \mathrm{DIN}$ が $2-10$ $\mu$ g-at.N/L, DIP が 0.2-1.0 $\mu$ g-at.P/L, Chl. a が 1-10 $\mathrm{mg} / \mathrm{m}^{3}$, ランク $\mathrm{V}$ (貧栄養) では透明度が $10 \mathrm{~m}$ 以上, COD が $1 \mathrm{O}_{2} \mathrm{ppm}$ 以下, DIN が $2 \mu \mathrm{g}$-at.N/L 以下, DIP が $0.2 \mu \mathrm{g}$-at.P/L 以下, Chl. a が $1 \mathrm{mg} / \mathrm{m}^{3}$ 以下となり, ランク II (弱過栄養) およびランク IN (弱富栄養) はそ れぞれ前後のランクの中間となる. 
表-2 海域環境のランク分けと各ランクに相当する環境指標項目および付着生物の該当種類

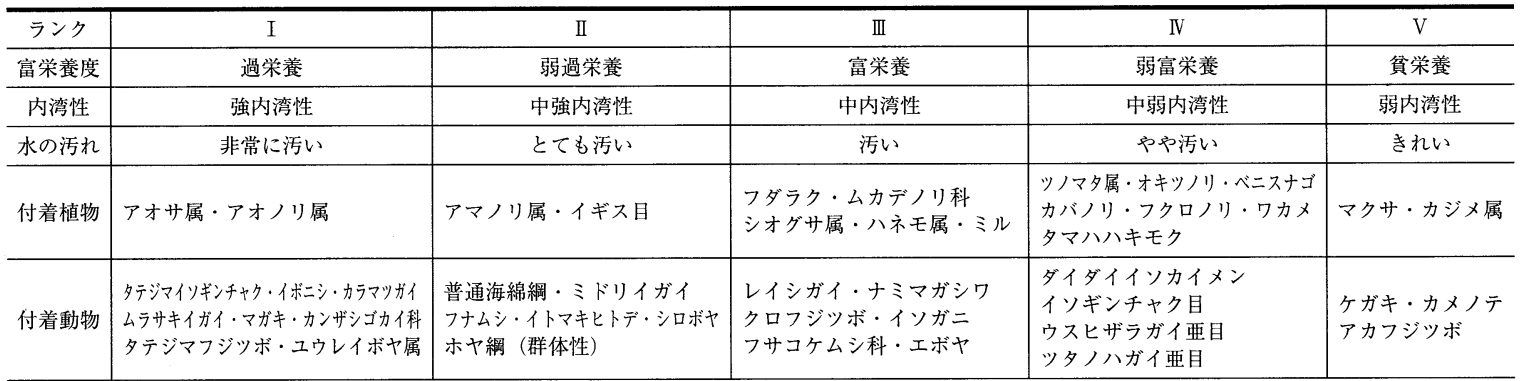

\section{（2）既知の指標生物のランク分け}

フィールド調查により確認された付着生物の種類のう ち，既知の指標生物は，新崎（1975），梶原（1975），吉 田（1983），横浜市環境保全局（2002）および吉村ほか （2005）を参考に，一部の種では所属する上位分類群 （属，科および亜目）を指標生物と見なし，付着植物で は 13 種類, 付着動物では 15 種類, 合計 28 種類が挙げ られた．既知の指標生物各種および分類群を表-1(a)お よび表-1(b)の各表中のの印で示した。これら指標生物 が指標する海域環境に基づき，既知の指標生物を前項で 設定した各ランクにそれぞれ振り分けた（表-2）.

（3）その他の付着生物のランク分け

フィールド調査により確認された付着生物の種類のう ち, 既知の指標生物以外の種類については, 各種類の生 理および生態を参考に，前項でランク分けした既知の指 標生物の調査地点別の出現状況を基準として，各種類の 出現状況を照合し，両者の出現状況の類似性に基づいて 相当するランクを類推して振り分けた（表-2）。これに より, 既知の指標生物の出現が無い調查地点の評価が可 能となる。

\section{（4）生物相評価指数の算出方法}

潮間帯の付着生物相に基づいて調査地点の海域環境を
数值評価するため, 先の 5 段階のランクに対し, I から $\mathrm{V}$ の順に $1 ， 3 ， 5 ， 7 ， 9$ の点数を与えた. 各調査地点に おける付着生物の出現種類に基づき，付着植物および付 着動物に区分して，各ランク毎に 1 種類以上の該当する 種類があれば，ランクに対応する点数を与えることとし， 全 5 ランクの点数の合計值を該当のあったランク数で除 することにより付着植物相および付着動物相の定量評価 指数（小数第二位四捨五入）をそれぞれ算出した。これ らの指数を生物相評価指数 (IF : Index of Flora and Fauna）とし，以降 IF と略記する．なお，同じランク に複数種類の該当があった場合の補正は行わない.

IF は， 1 種類以上の付着生物の出現があれば，計算 上 1.0-9.0 点の範囲を取り, 付着生物の出現が無い場合 は 0 点とする. ランク別の付着生物の出現状況と IF の 算出例を表-3に示した。一般に, 海域環境のランクが 低い調査地点では，特定の付着生物の種類に出現が限ら れる傾向が強いと考えられるのに対して，海域環境のラ ンクが高い調査地点では，多様な付着生物の種類が出現 する傾向が強いと考えられることから，フィールド調査 に打ける IF は，付着生物の出現が全ランクで見られる 場合（表-3のケース 5) に最大值 5.0 点を取ると予想さ れる。このことから，海域環境のランクに対する IF の

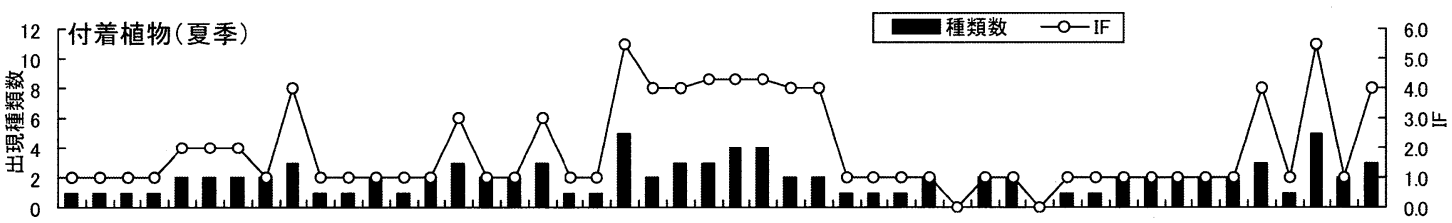

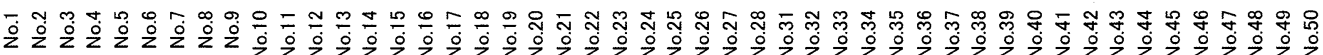

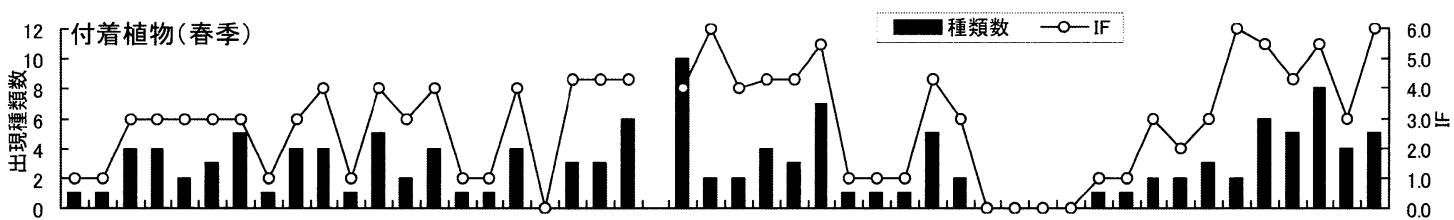

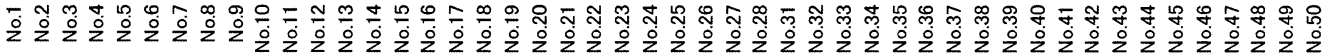

図-2(a) フイールド調査による付着植物の出現種類数および IF 


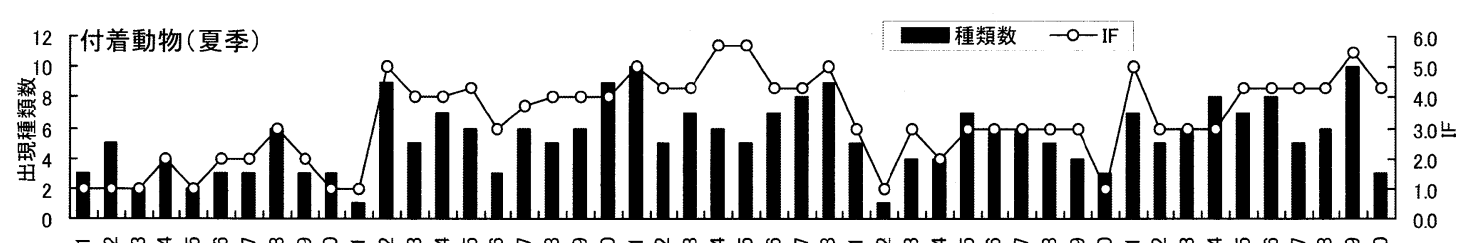

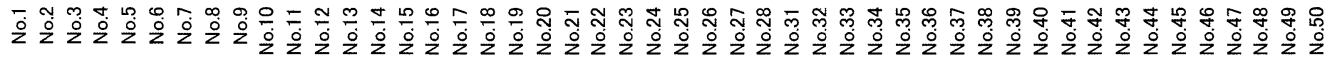

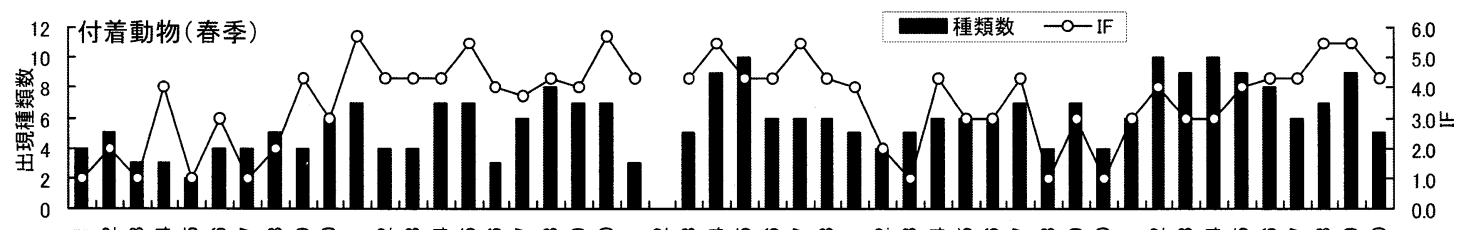

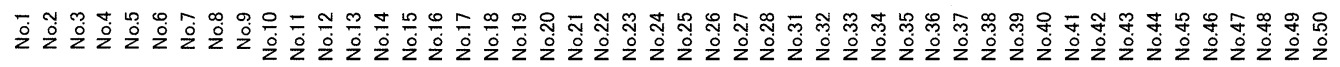

図-2(b) フィールド調査による付着動物の出現種類数および IF

目安として, ランク I が 1 前後, 以降, ランクが一つ増 える毎に IF は 1 ずつ高くなり, ランクVの IF は 5 前 後と予想される.

\section{（5）生物相評価指数の算出結果}

フィールド調査による付着植物の出現種類数および IF を図-2(a)に示した. 付着植物相の IF は，夏季では 最大 5.5 点, 最小 0 点、全 48 調査地点の平均は 1.9 点, 春季では最大 6.0 点, 最小 0 点, 全地点の平均は 2.9 点 であり，夏季に比べて上昇した。

フィールド調査による付着動物の出現種類数および IF を図-2(b)に示した. 付着動物相の IF は，夏季では 最大 5.7 点, 最小 1.0 点, 全 48 調查地点の平均は 3.3 点, 春季では最大 5.7 点, 最小 1.0 点, 全地点の平均は 3.6 点であり, 夏季に比べてやや上昇した.

\section{4. 考察}

\section{（1）生物相評価指数の変化傾向}

フィールド調査による付着生物の IF を見ると, 付着 植物及び付着動物とも夏季に比べて春季の方が高い值を 示し, 海域環境が良好であると評価できた。これは, 季 節変化に伴って付着生物相に変化が生じたためであり, その要因としては, 水温等の海域環境の変化による影響,

表-3 ランク別の付着生物の出現状況と IF の算出例

\begin{tabular}{c|c|c|c|c|c|c}
\hline ランク & 点数 & ケース 1 & ケース 2 & ケース 3 & ケース 4 & ケース 5 \\
\hline $\mathrm{I}$ & 1 & 有 & 有 & 有 & 有 & 有 \\
\hline $\mathrm{II}$ & 3 & 無 & 有 & 有 & 有 & 有 \\
\hline III & 5 & 無 & 無 & 有 & 有 & 有 \\
\hline $\mathrm{IV}$ & 7 & 無 & 無 & 無 & 有 & 有 \\
\hline $\mathrm{V}$ & 9 & 無 & 無 & 無 & 無 & 有 \\
\hline 点数合計 $(\mathrm{T})$ & 1 & 4 & 9 & 16 & 25 \\
\hline 出現ランク数 (C) & 1 & 2 & 3 & 4 & 5 \\
\hline IF (T/C) & 1.0 & 2.0 & 3.0 & 4.0 & 5.0 \\
\hline \multicolumn{2}{r|}{}
\end{tabular}

並びに付着生物の各種類が有する生活史の特性等による ものと考えられる.なお，付着植物については，夏季の 透明度の低下による水中光量の減少による影響が考えら れ, 付着動物については, 夏季の筫酸素化による溶存酸 素の減少による影響が考えられるが，潮間带を対象とす るため, その影響は小さいと考えられた.

また，付着動物の IF は付着植物に比べて高い傾向を 示した。これは，基盤に固着し，光合成により生長する 付着植物に対して，一部の固着動物を除き，基盤表面を 移動し，呼吸により酸素を消費し，摂䭒により成長する 付着動物とでは海域環境の関わり方が大きく異なり，付 着動物に比べて付着植物の方が生育条件としてょり良好 な海域環境を必要することを示唆するものと考えられた。

（2）生物相評価指数と水質の相関関係

兵庫県 (1999-2004)，大阪府 (2000-2005)，大阪府立 水産試験場（2001-2005）より，フィールド調查地点に

表-4 フィールド調査地点に対応させた水質測定地点

\begin{tabular}{|c|c|c|}
\hline フィールド調査 & 水質測定 & 文献（測定地点） \\
\hline $49-50$ & A & 兵庫県（No.70） \\
\hline 48 & B & 兵庫県 (No.67) \\
\hline $46-47$ & $\mathrm{C}$ & 兵庫県（No.66） \\
\hline $44-45$ & D & 兵庫県（No.62） \\
\hline $41-43$ & $\mathrm{E}$ & 兵庫県（No.65） \\
\hline $38-40$ & $\mathrm{~F}$ & 大阪府立水産試験場（No.18） \\
\hline $34-37$ & G & 大阪府 $(\mathrm{O}-3)$ \\
\hline $31-33$ & $\mathrm{H}$ & 大阪府 (C-3) \\
\hline $1-2$ & I & 大阪府（S-1）·大阪府立水産試験場（No.17） \\
\hline 3-5 & $\mathrm{J}$ & 大阪府 $(\mathrm{C}-4)$ \\
\hline $6-10$ & $\mathrm{~K}$ & 大阪府立水產試験場（No.13） \\
\hline $11-18$ & $\mathrm{~L}$ & 大阪府 $(\mathrm{C}-5)$ \\
\hline $19-21$ & $\mathrm{M}$ & 大阪府立水产試験場（No.19） \\
\hline $22-27$ & $\mathrm{~N}$ & 大阪府 $(\mathrm{A}-3)$ \\
\hline 28 & $\mathrm{O}$ & 大阪府立水産試験場（No.11） \\
\hline
\end{tabular}


相関係数

$\begin{array}{lllllll}0.3 & 0.4 & 0.5 & 0.6 & 0.7 & 0.8 & 0.9\end{array}$

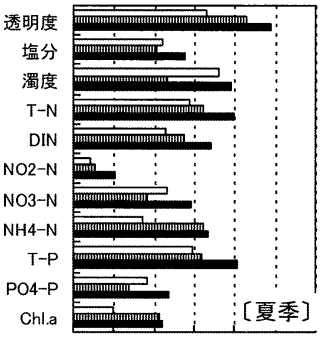

相関係数

$\begin{array}{lllllll}0.3 & 0.4 & 0.5 & 0.6 & 0.7 & 0.8 & 0.9\end{array}$

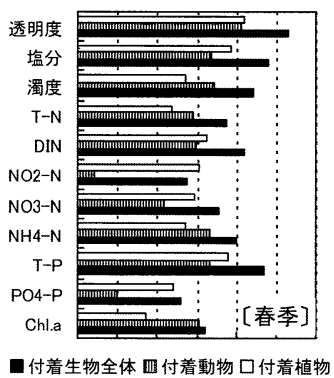

口付着生物全体 四付着動物口付着植物

図-3 調査地点別の IF と水質の相関分析結果
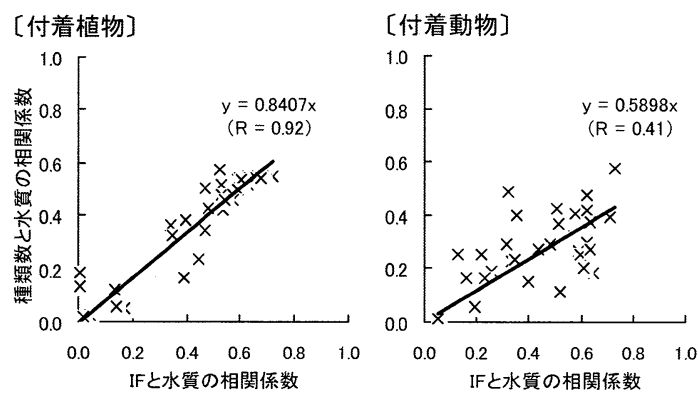

図-4 IF および出現種類数と水質の相関分析結果の比較

近い公共用水域水質測定地点及び浅海定線調査地点 16 地点の過去 5 年間（1999 2003）の平均值を集計し, IF と水質 16 項目（透明度，水温， $\mathrm{pH}, \mathrm{DO}$, 塩分, 濁 度, SS, COD, T-N, DIN, $\mathrm{NO}_{2}-\mathrm{N}, \mathrm{NO}_{3}-\mathrm{N}, \mathrm{NH}_{4}-\mathrm{N}$, T-P, $\mathrm{PO}_{4}-\mathrm{P}, \mathrm{Chl}$. a) の平均值の相関分析を行った. フィールド調查地点に対応させた水質測定地点を表-4, 調査地点別の IF と水質の相関分析結果を図-3にそれぞ れ示した。

付着植物および付着動物の IF では透明度のみ，相関 係数 0.7 以上の高い相関が見られ，付着生物全体として 両者を加算した合計值では透明度, 塩分, 濁度, T-N, DIN, $\mathrm{NH}_{4}-\mathrm{N}, \mathrm{T}-\mathrm{P}$ の 7 項目で相関係数 0.7 以上の高 い相関が見られた。

\section{（3）生物相評価指数と出現種類数の比較検討}

IF の有用性を検討するため, 生物調査により海域環 境を評価する際に最も基本的な指標となる出現種類数を 比較対照として, 出現種類数と前項の水質の相関分析を 行った. IF および出現種類数と水質の相関分析結果の 比較を図-4に示した，付着植物および付着動物とも， IF との相関係数の方が高い傾向を示すことが分かった. このことから，IFによる海域環境の評価は出現種類数 に比べて有用性が高いと評価できた。

\section{5. 結 論}

本研究では，指標生物の特性を利用した生物相による 海域環境の新しい数値評価方法として，指標生物法の欠 点を補った生物相評価指数 (IF) を提案し, IF と水質 の相関関係から有用性が高いことを示した。

また，海域環境の最も直接的な指標は水質であるが， 現地観測される水質デー夕は瞬間值であるため，一時的 な海域環境の側面しか捉えられず，同時に多くの地点の デー夕を得ることも難しい。これに対して，移動性にそ しい付着生物のデータの場合，海域環境の積分值に相当 するものと考えられ，付着生物相の IF による海域環境 の評価は，水質の欠点をカバーできるものと言える.

今後は, データの蓄積, 他の海域および生物群等に適 用範囲を拡大するとともに，簡易な評価方法である特性 を活かして環境教育等への応用を試みたい.

最後に，本研究を進めるに当たり，フィールド調査の 機会を与えていただいた生態系工学研究会, フィールド 調査に参加された生態系工学研究会の会員諸氏，堺市漁 業協同組合の関係各位，調査等に協力いただいた総合科 学 (株) 海域環境部のスタッフに感謝します.

\section{参 考 文 献}

新崎盛敏 (1975)：生物指標としての海藻，環境と生物指標 2 (水 界編)，共立出版，pp. 215-224.

伊藤信夫 (1998)：環境指標生物, 沿岸の環境圏, フジ・テクノシ ステム, pp. 814-831.

大阪府 (2000-2005)：公共用水域水質測定調查，平成 10-15 年度大 阪府域河川等水質調査結果報告書.

大阪府立水産試験場 (2001-2005)：浅海定線調查，平成 11-15 年度 大阪府立水産試験場事業報告.

奥谷喬司 (2000)：日本近海産貝類図鑑，東海大学出版会.

梶原武 (1975)：海洋環境の指標としての付着動物, 環境と生物指 標 2 (水界編)，共立出版，pp. 274-283.

田中次郎・中村庸夫 (2004)：日本の海藻（基本 284）, 平凡社. 西村三郎 (1992)：原色検索日本海岸動物図鑑（I），保育社. 西村三郎 (1995)：原色検索日本海岸動物図鑑（II），保育社. 兵庫県 (1999-2004)：公共用水域水質測定調査, 平成 10-15 年度公 共用水域の水質等測定結果報告書.

八杉龍一・小関治男 - 古谷雅樹 - 日高敏隆編 (1996)：生物分類表, 岩波生物学辞典（第 4 版）, 岩波書店, pp. 1535-1617.

横浜市環境保全局 (2002)：生物指標から見た水質污染状況，横浜 の海岸の生きものたち（川と海の生き物シリーズ 6).

吉田陽一(1983)：生物指標法, 漁業環境アセスメント（吉田多摩 夫編), 水産学シリーズ 48, 恒星社厚生閣, pp. 25-46.

吉村直孝 ·上月康則 · 三好順也 - 村上仁士 - 龟田大悟 (2005)：小 型水中カメラを用いた直立構造物に扔ける簡易的な付着生物 調查方法の提案, 海洋開発論文集, 第 21 巻, pp. 241-246. 